\title{
Detecting the Carotenoid Pigmentation due to Haloarchaea Microbes in the Lonar Lake, Maharashtra, India Using Sentinel-2 Images
}

\author{
Rajarshi Bhattacharjee ${ }^{1} \cdot$ Abhinandan Choubey $^{1} \cdot$ Nilendu Das $^{1}$ (D) $\cdot$ Anurag Ohri $^{1} \cdot$ Shishir Gaur $^{1}$
}

Received: 4 August 2020 / Accepted: 20 October 2020/Published online: 23 October 2020

(C) Indian Society of Remote Sensing 2020

\begin{abstract}
The Lonar Lake of Maharashtra is a crater based-saline lake. During the month of June 2020, this lake suddenly changed its colour and turned to pink due to the presence of Haloarchaea microbes, and this species have a unique adaptation style to survive in high saline condition. The salinity of this lake is increasing due to less rainfall, low human intervention, and an increase in the temperature of this region. These microbes produce fantastic bloom, which can be sensed from outer space because of red-orange carotenoids production. In this work, Sentinel 2A datasets have been used for the duration of January 2020 to June 2020. These datasets have been processed in Google Earth Engine platform and several indices like Salinity Index, Surface Algal Bloom Index, and Normalized Difference Haloarchaea Index have been calculated. With the help of these indices, it has been found that the appearance of these microbes has happened in the early part of June 2020, and in more precise terms, it can be stated that between May 31 and June 5, these microbes have appeared in the lake.
\end{abstract}

Keywords Lonar lake $\cdot$ Haloarchaea $\cdot$ Sentinel 2A $\cdot$ Google earth engine $\cdot$ Salinity index $\cdot$ Normalized difference haloarchaea index

\section{Introduction}

The most valuable natural resource on the earth is freshwaters, and lakes around the world have the quantity of freshwater in abundance. Lakes are the abode for various species, and it can bestow humanity with several ecosystem services. The problem of fresh and clean drinking water is a matter of global concern, and lakes can actually act as a source of remedy for this menace because lakes mostly contain freshwater, which can be used for drinking

Nilendu Das

dasnilendu2016@gmail.com

Rajarshi Bhattacharjee

rajbhatt78645@gmail.com

Abhinandan Choubey

choubey.civ18@itbhu.ac.in

Anurag Ohri

aohri.civ@iitbhu.ac.in

Shishir Gaur

shishirg.civ@iitbhu.ac.in

1 Department of Civil Engineering, Indian Institute of Technology (BHU), Varanasi 221005, India purposes. Some of the lakes can be used for aquaculture purposes, which can provide a source of commercial income to the people associated with it (Jia et al. 2015; Sterner et al. 2020).

There are few impact crater lakes across the world, and one of these is the Lonar crater lake situated in the Buldhana district of the state Maharashtra, India. Lonar crater lake had formed due to the collision of a massive meteorite with the earth approximately around 50,000 years earlier. The weight of the meteorite was about 20 lakh tonnes, and it collided with a velocity of $25 \mathrm{~km} / \mathrm{sec}$ (Mahto and Kushwaha 2018). Lonar crater is filled with saline water. This is the thirdlargest natural saltwater lake in the world. The water in this lake shows saline and highly alkaline properties, so it can also be termed as soda lake. Lonar Lake is entirely closed, and it does not have any outlet. It has unique limnology and ecological biodiversity (Tambekar et al. 2010; Tambekar and Dhundale2012). In this soda lake, indigenous microbes show their presence, which can thrive under alkaline conditions. From the Lonar Lake silt sample, the alkaline metalloprotease from alkaline Streptomyces has been isolated. Alkaliphilic bacteria have also been isolated from Lonar Lake sediments. Several other bacterial species of the genera 
Fig. 1 Study area map

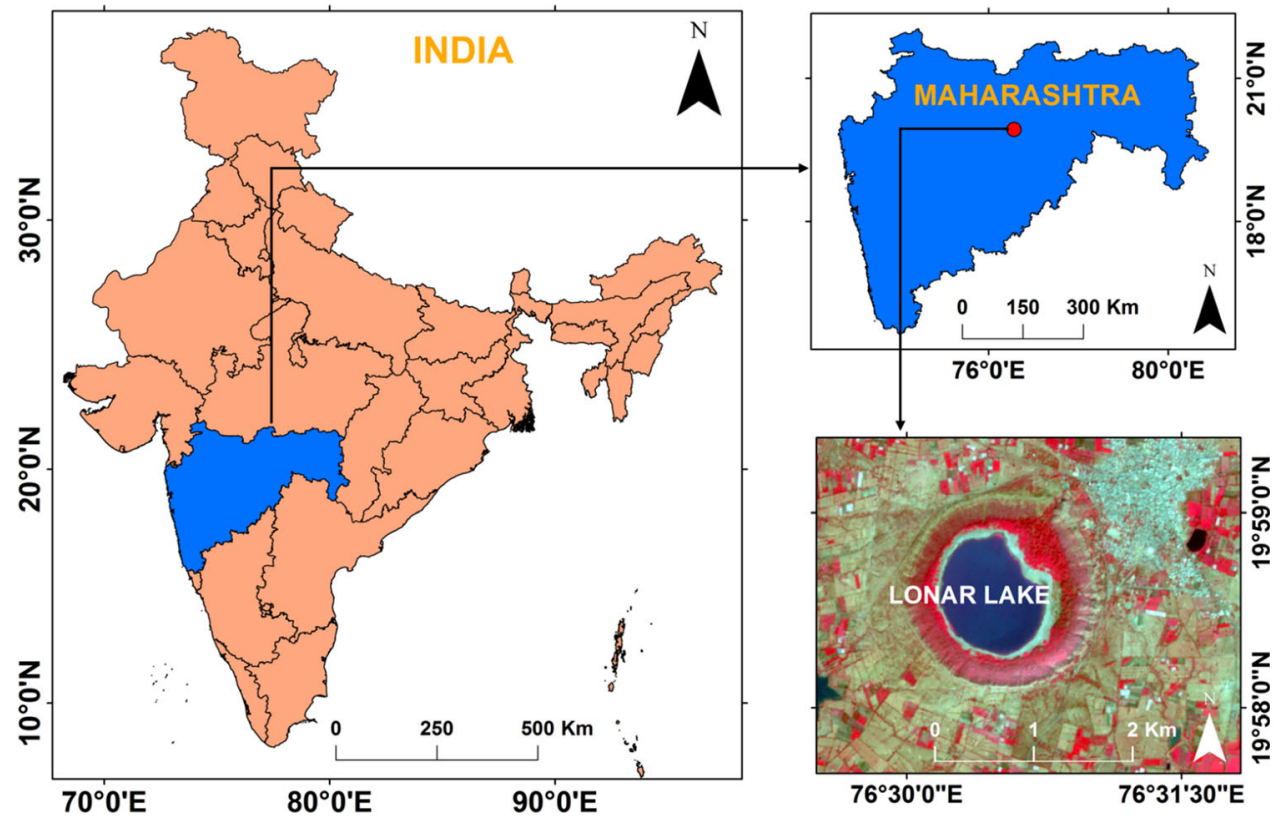

like Bacillus, Arthrobacter, Micrococcus, Planococcus, Dietzia, Vagococcus, Exigobacterium, have been found in this lake. Eutrophication and the presence of blue-green algae have also been indicated by some of the researchers. In the peripheral region of the Lonar lake, several trees are present and, litter also gets accumulated at the periphery of the lake. Green algae grow in significant numbers along the bank of the lake. Some studies have shown that the colour of the lake water fluctuates between pale green to dark green because of the extremely dense algal population mostly dominated by Spirulina (Yannawar and Bhosle 2013). Due to this presence of trees, fecal matter, and green algae, this lake becomes organically very rich (Joshi et al. 2008; Yannawar and Bhosle 2013).

Remote sensing technology and satellite-based imageries are nowadays used progressively for measuring the algal bloom in the water bodies. This technology can be explained as the technique of computing the physical properties of distant objects using reflected or emitted energy. Remote sensing data, with its ability for a synoptic view, repetitive coverage with calibrated sensors to detect changes, observations at different resolutions, provides a better alternative for natural resources management as compared to traditional methods (Budd et al. 2001; Roy et al. 2017). For processing the satellite images, Google

Table 1 Characteristics of the S2A bands used

\begin{tabular}{lll}
\hline Sentinel-2 Bands & Central wavelength $(\mathrm{nm})$ & Spatial resolution $(\mathrm{m})$ \\
\hline Band 2-Blue & 490 & 10 \\
Band 3-Green & 560 & 10 \\
Band 4-Red & 665 & 10 \\
Band 8-NIR & 842 & 10 \\
\hline
\end{tabular}

had created modern technology in the year 2010, and it is known as GEE (Google Earth Engine). It is a cloud-based computational technique that can process massive satellite datasets, and this technology is freely available on the internet platform. GEE has huge numbers of servers around the globe, and it allows parallel processing of trillions of images (Dong et al. 2016; Zurqani et al. 2018).

Some of the recent online articles and media reports stated that the colour of the Lonar lake has turned to pink during the early week of June 2020 (Parab 2020; Pinjarkar 2020). Media is saying that due to the absence of rainfall, low gathering of people nearby lake because of lockdown (COVID-19 scenario has forced the Indian government to declare lockdown in the country), and high temperature have resulted in rapid evaporation which in turn increased the salinity and $\mathrm{pH}$ of the lake water. The increased salinity and $\mathrm{pH}$ facilitated the growth of halophilic microbes, mainly Haloarchae ("Lonar lake in Maharashtra's Buldhana district turned pink due to 'Haloarchaea' microbes: probe," 2020; "Lonar Lake Tries On a Rosy Colour," 2020). Genomic analysis has shown that Haloarchae consists of highly acidic proteomes. Due to this acidic proteomes, these microbes develop unique adaptability in the high saline environment by balancing the sodium ions in their environment with potassium. Osmotic equilibrium, along with high internal salt concentration, has been maintained by these microbes (Kennedy et al. 2001; DasSarma and DasSarma 2017). These microbes give rise to the remarkable blooms detectable from space due to the synthesis of red-orange isoprenoid carotenoids (DasSarma et al. 2020).

In this analysis, satellite imageries have been used to detect this bloom in the Lonar lake due to the presence of 
Fig. 2 Spectral signature of the Haloarchaea infected lake water

Fig. 3 Methodology Flowchart for indices calculation in GEE Environment
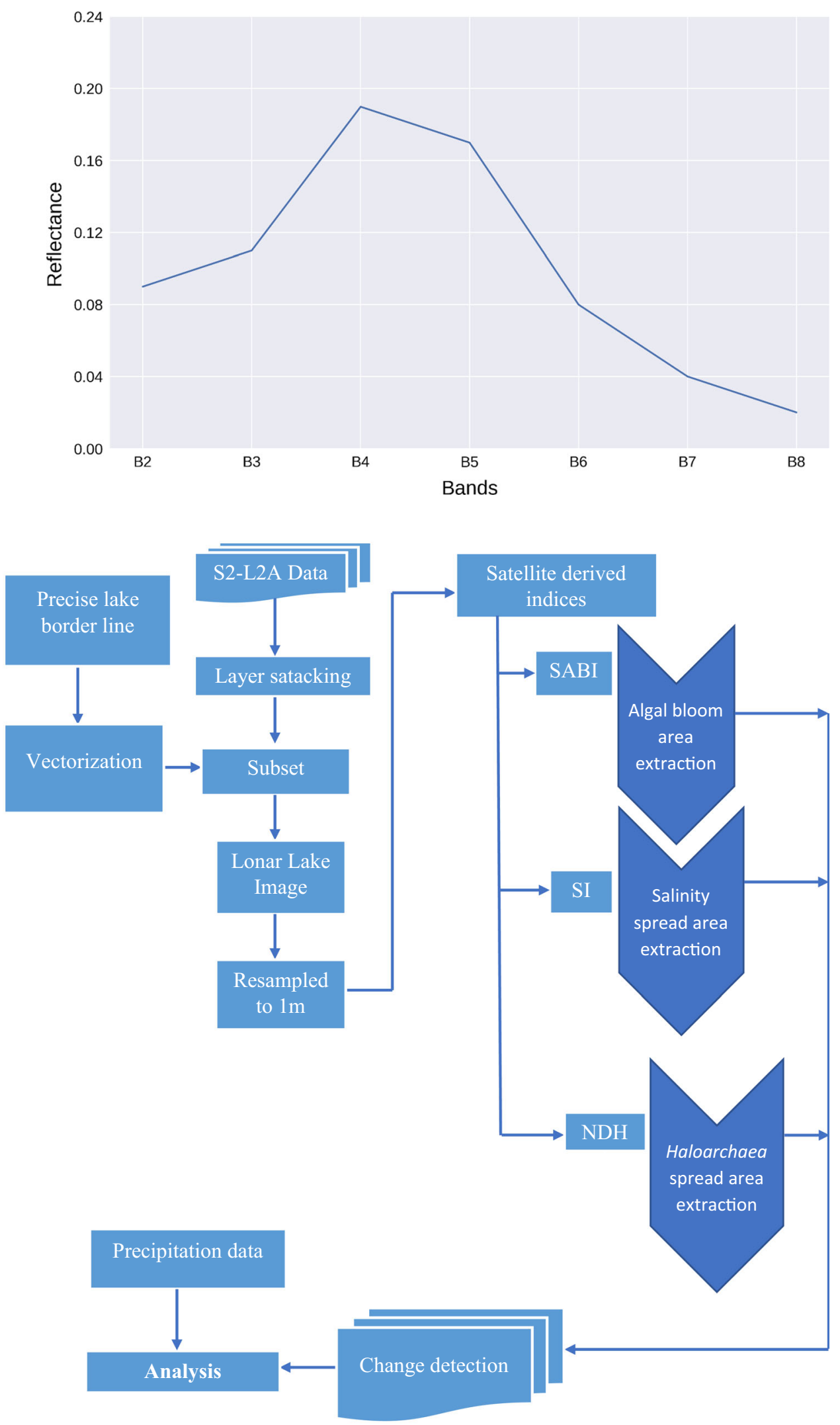

Haloarchaea microbes. The images have been processed in the GEE domain to detect the salinity, algae spread, and microbial bloom in the lake from January 2020 to June 2020. 

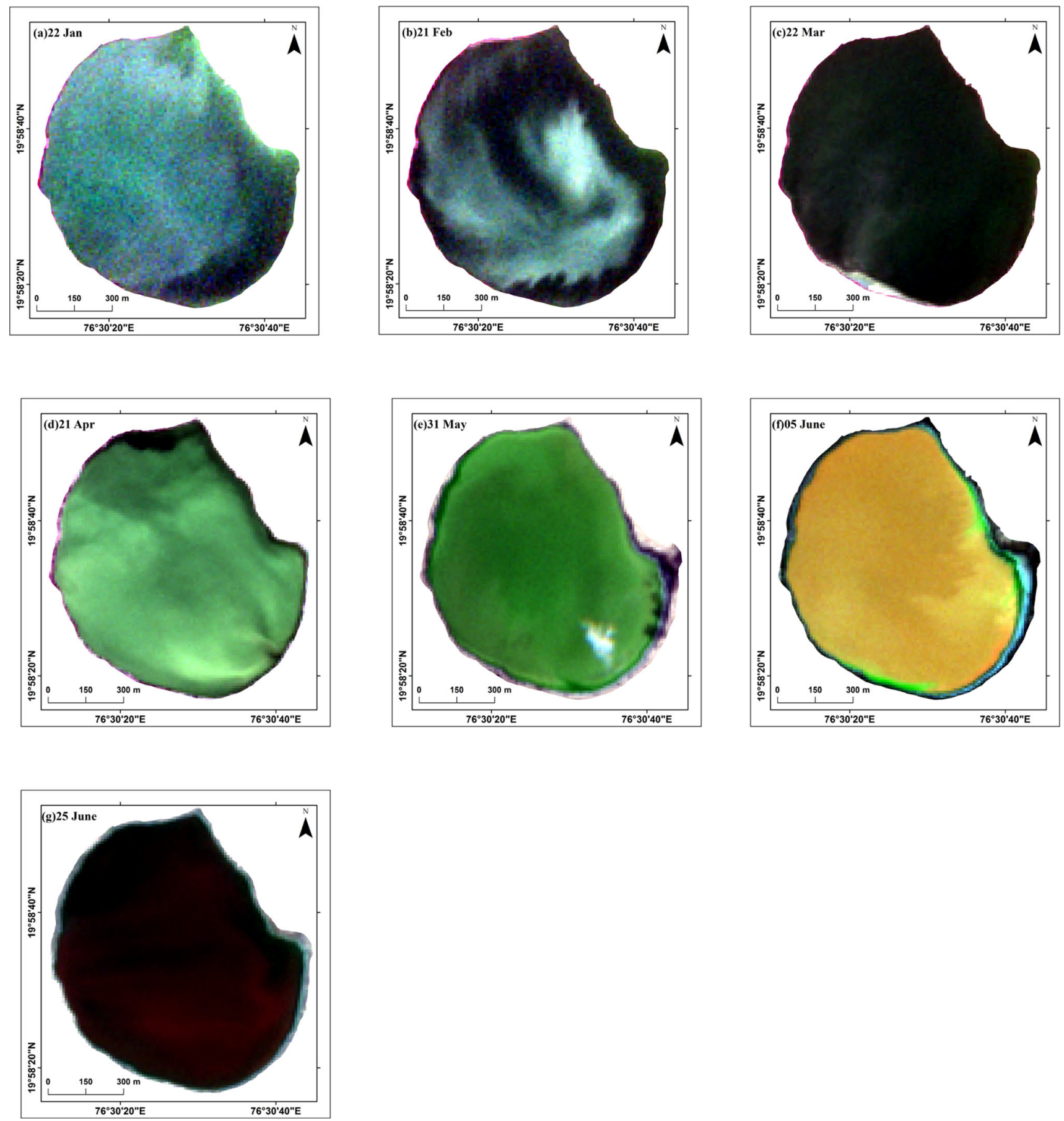

Fig. 4 TCC images for Lonar Lake

\section{Material and Methods}

\section{Study Area}

Lonar lake is situated nearby the Lonar township of the Buldhana district of Maharashtra, India. Its geographical position is $19^{\circ} 58^{\prime} \mathrm{N} \& 76^{\circ} 31^{\prime} \mathrm{E}$. The nature of the climate in this region is tropical Savanna climate, and the average precipitation in this area is $750 \mathrm{~mm}$ annually. Rainfall mostly occurs from the month of July to September. The average summer and winter temperature in this region is $20{ }^{\circ} \mathrm{C}$ and $34^{\circ} \mathrm{C}$ respectively. The duration of the summer season in this part is mostly from March to June. The alkalinity and salinity of this lake surge during the summer season. The average alkalinity varies from $\mathrm{pH}$ 9.5-10.0. This lake is also rich in carbonates and bi-carbonates 

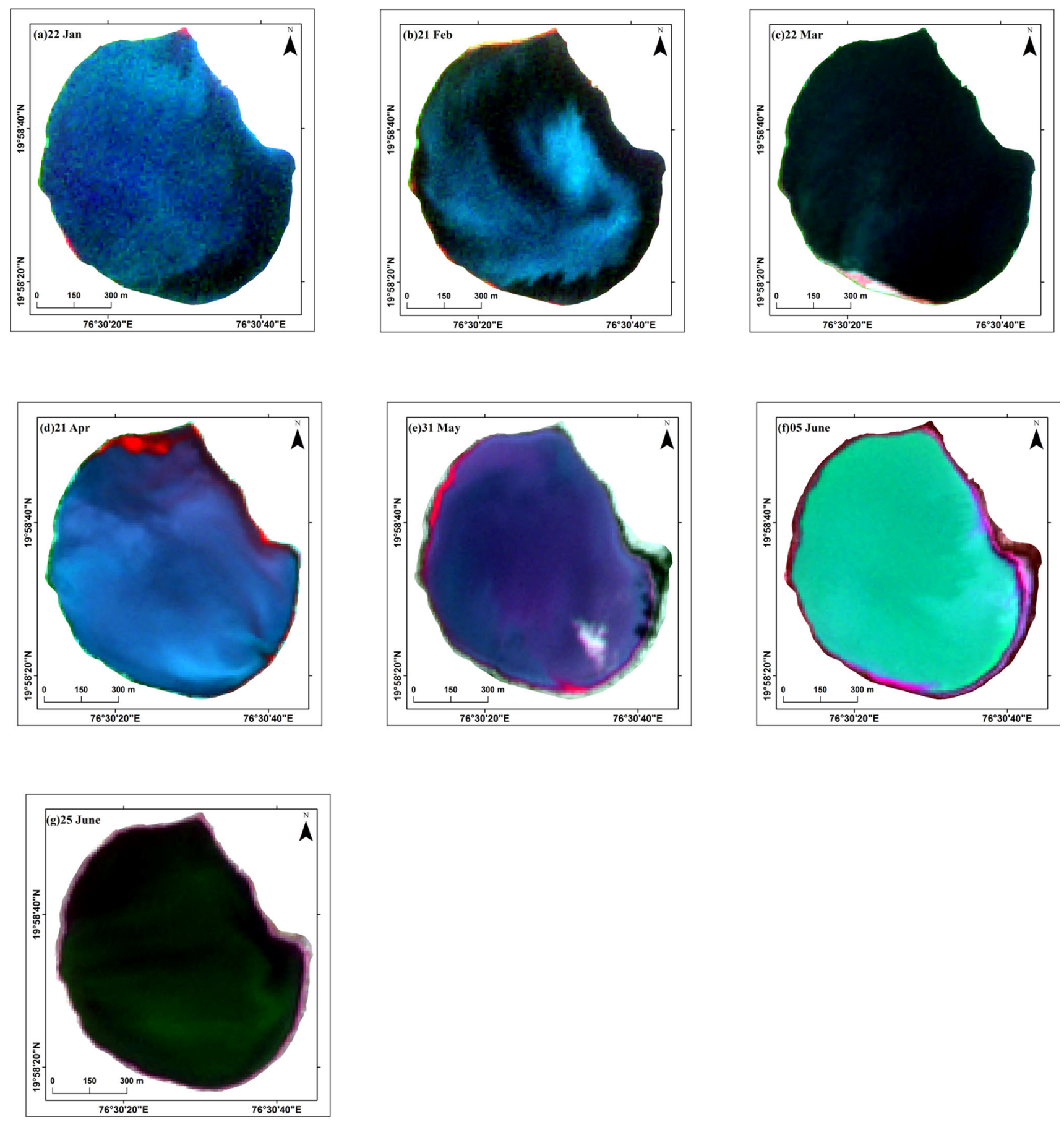

Fig. 5 SFCC images for Lonar Lake

minerals (Yannawar and Bhosle 2013; Mahto and Kushwaha 2018). The study area map has been given in Fig. 1.

\section{Data Used}

Sentinel 2A (S2A) satellite images have been used in this study. This satellite is a part of the Copernicus Sentinel 2 mission. S2A MSI (multispectral instrument) satellite was commissioned in orbit in 2015, and Sentinel 2B (S2B) MSI was sent to the orbit in 2017. S2A images have great usage for studying lake ecology and also for retrieving the water quality indicators at a fine scale (Bresciani et al. 2018). S2A images available in GEE are considered to be Level 2 products ( $\mathrm{Li}$ et al. 2019). The revisit time of $\mathrm{S} 2 \mathrm{~A}$ is ten days, but it decreases to five days when both the imagers are operational as compared to LANDSAT-8 satellite, 

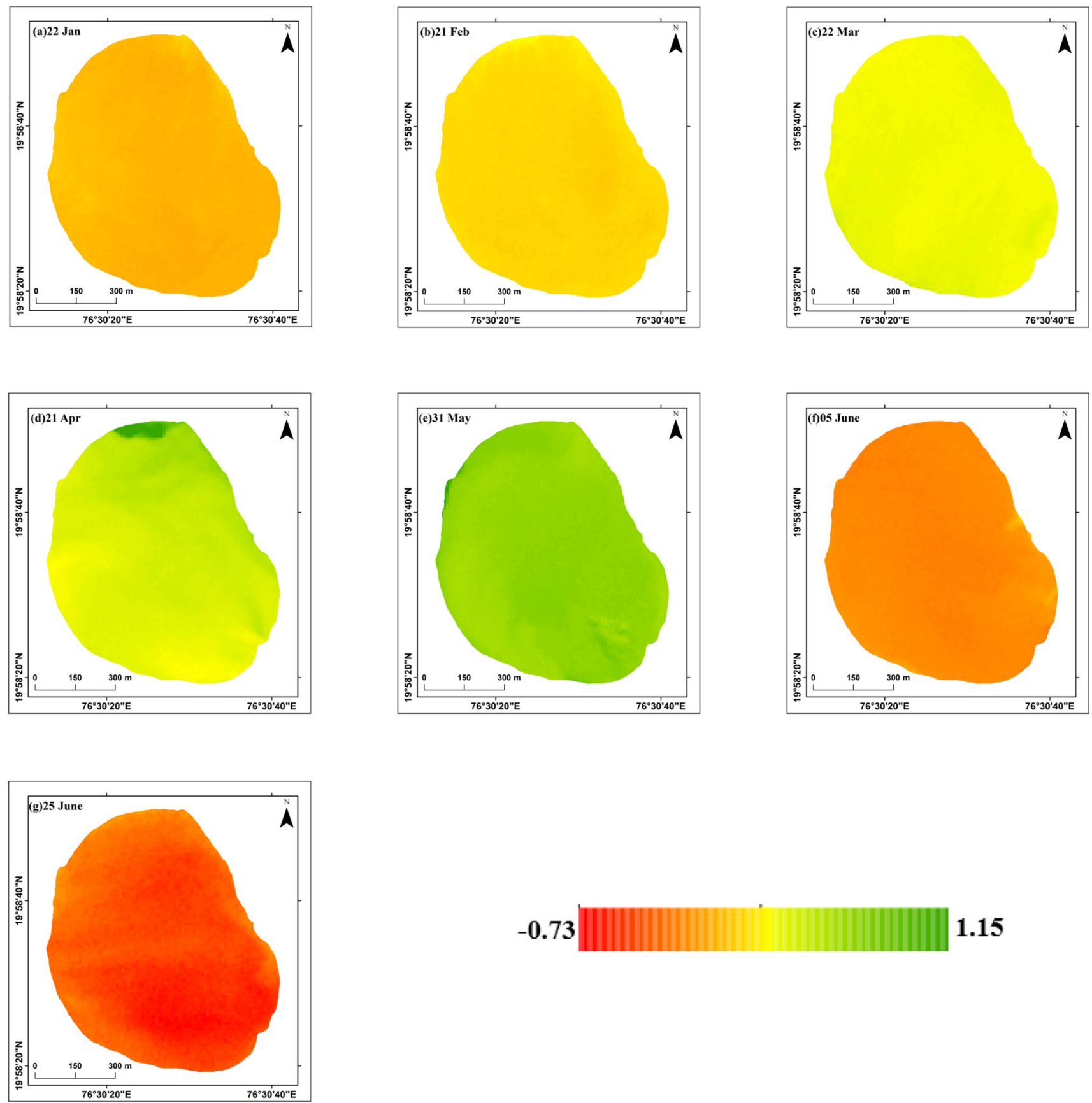

$-0.73$

1.15

Fig. 6 Variation of SABI in Lonar lake

which has 16 days revisit time. The blue, green, red, and NIR (Near Infra-Red) bands has 10-m spatial resolution as compared to the 30-m spatial resolution of these bands in LANDSAT-8 (Roy et al. 2014; Van der and Van der 2016; Gorji et al. 2020). The images have been processed in Google Earth Engine (GEE) platform. Corresponding to the latest datasets, S2A images that completely covered the Lonar lake area are collected from January 2020 to June 2020. The single image of each month starting from January to May 2020 and two images of June 2020 have been considered for this study. The characteristics of the bands used in this analysis is given in Table 1.

\section{Image Processing by GEE}

\section{Indices Calculation}

S2A images dated 22 January, 21 February, 22 March, 21 Aril, 31 May, 5 June, and 25 June 2020 have been processed in GEE for calculating indices like SI (Salinity 
Table 2 Statistical parameters of SABI

Surface algal bloom index (SABI)

\begin{tabular}{lcccl}
\hline Date & Min & Max & Average & SD \\
\hline 22 Jan & -0.05 & 0.21 & 0.02 & 0.03 \\
21 Feb & 0.002 & 0.39 & 0.08 & 0.03 \\
22 Mar & 0.09 & 0.57 & 0.15 & 0.02 \\
21 Apr & 0.12 & 1.15 & 0.24 & 0.18 \\
31 May & 0.11 & 1.09 & 0.35 & 0.041 \\
5 Jun & -0.45 & 0.06 & -0.25 & 0.02 \\
25 Jun & -0.73 & -0.23 & -0.41 & 0.12 \\
\hline
\end{tabular}

Index), SABI (Surface Algal Bloom Index) (Alawadi 2010; Gorji et al. 2020). SI is statistically very dynamic (Khan and Abbas 2007). SABI is very robust in nature because it uses a four-band ratio-based relationship which can distribute the weight of each optical response proportionally, and the use of green, blue bands in the denominator makes this index highly viable for detecting the algal bloom spread over the water surface (Alawadi 2010). For detecting the pigment released from Haloarchaea, an index has been applied by considering red and NIR bands. The spectral signature have been generated for the Lonar lake image of 25th June 2020. This image shows the highest concetration of Haloarchaea microbes. The spectral signature shows peak in red band (Band 3) and trough in NIR band (Band 8) (Fig. 2).

Reflectance values are considered for calculating these indices (Gorji et al. 2020), (Alawadi 2010).

SI $=\frac{\text { Band Blue } \times \text { Band Red }}{\text { Band Green }}$

$\mathrm{SABI}=\frac{\text { Band NIR }- \text { Band Red }}{\text { Band Blue }+ \text { Band Green }}$

The index for calculating the pigment of Haloarchea is normalized by taking the red and NIR bands into consideration.

Normalized Difference Haloarchea index (NDHI)

$$
=\frac{\text { Band Red }- \text { Band NIR }}{\text { Band Red }+ \text { Band NIR }}
$$

All the above-mentioned indices are calculated in the GEE platform on the S2A images. The overall approach for calculating the indices have been shown in Fig. 3. It processes all the S2A images of the required dates within a short time frame. The shapefile of the Lonar Lake has been drawn in the Google Earth Pro software, and that shapefile has been imported to the GEE domain.
TCC (True Colour Composite) Images and SFCC (Standard False Colour Composite) Images

True colour images will show the actual colour which our naked eyes can perceive and interpret. This kind of colour composites consists of Blue, Green, and Red bands in the visible region of the electromagnetic spectrum. Images of the month of April 2020 and May 2020 have a green colour, and the image of 5 June 2020 shows a reddish colour composition (Fig. 4).

SFCC needs to be used because human eyes can't perceive in the NIR region of the electromagnetic spectrum. The NIR becomes red, red becomes green, and green becomes blue in SFCC scheme. The image of the lake on 5 June 2020 shows a green colour in SFCC because originally, it has a red composition in it. The images of April 2020 and May 2020 are having blue colour because originally, they are green (Fig. 5).

\section{Results and Discussion}

\section{Variation of the algal bloom from January 2020 to June 2020}

The algae shows a constant rise in the Lonar lake from January 2020 to May. During April and May, the bloom is at its peak. The whole of the lake has been covered with the algae spread. Then in June 2020, the algae show a decreasing trend. The positive value of SABI means algae are exhibiting the photosynthesis activity. Negative SABI indicates that either the species goes deeper into the water column, which in turn leads to high water absorption in NIR and preventing the effect of red-edge from being sensed by the sensor or the species become photosynthetically inactive (Alawadi 2010). It can be possible that during the month of June 2020, Haloarchaea shows their presence in the lake, so the algal bloom goes deep into the water column (Fig. 6).

The range here is much more as compared to what other researcher has got (Alawadi 2010). This can be because the study area here is a lake which has a very much smaller dimension as compared to the sea, so here the concentration of the algae is much more as compared to seas. Thus, the range in this analysis gets much broader (Table 2).

\section{Variation in the Salinity from January 2020 to June 2020}

The salinity in the lake is increasing from January to April 2020. But in May, there is a sudden spurt in the concentration of the salinity at a particular portion in the lake. It can also be seen in Fig. 7. During the first week of June 

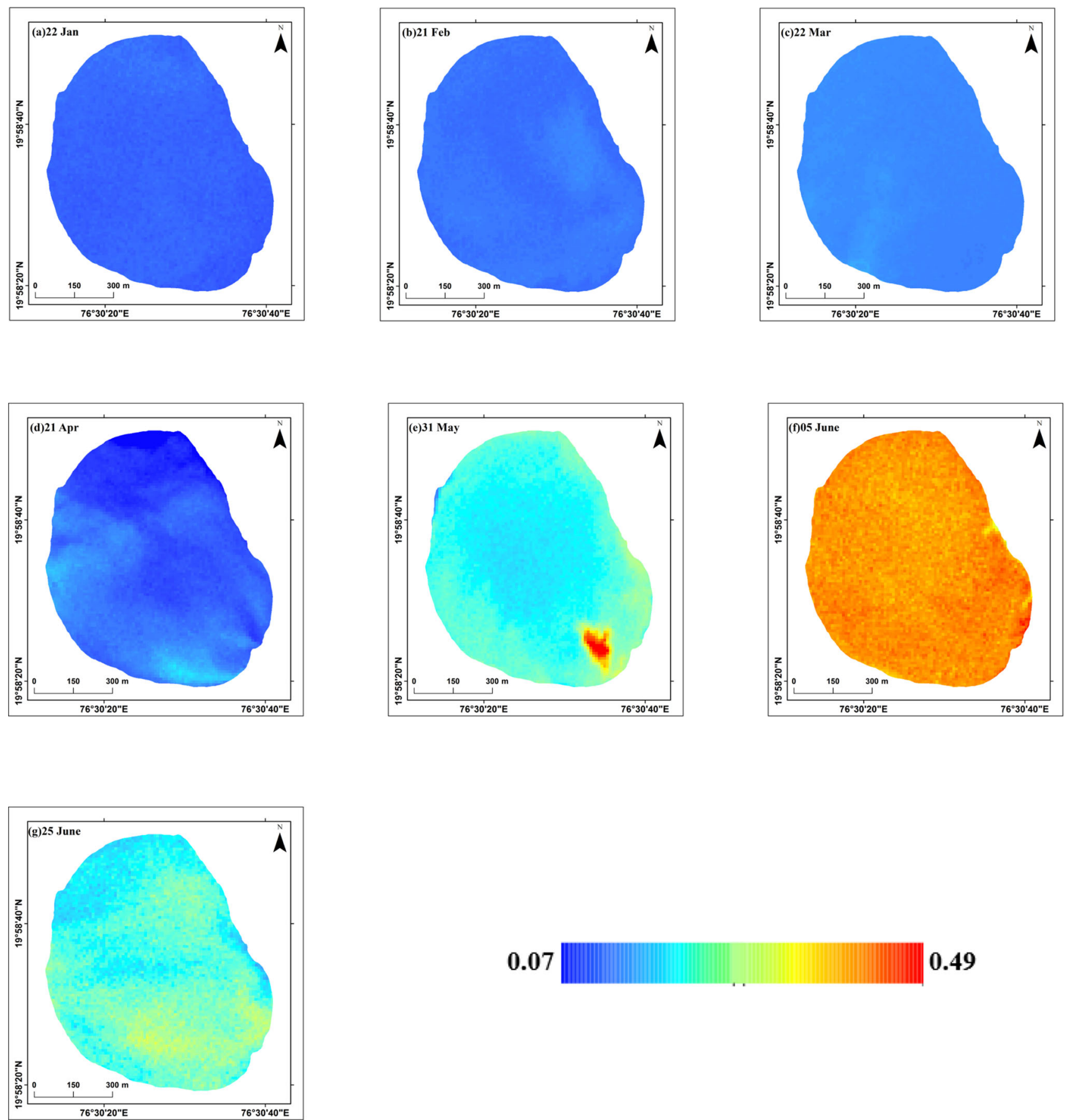

0.07

0.49

Fig. 7 Variation of SI in Lonar lake

2020, salinity becomes very high in the lake, but in the later part of the month, salinity somewhat shows a declining trend because of the rainfall in this region. The salinity gets dissolved a little bit, and it can be seen in the table that during June 25 salinity is lower than that of June 5.

\section{Variation in the Haloarchaea Concentration from January 2020 to June 2020}

The salinity was less in the lake from January to May 2020. In the month of May at a particular place, there is a considerable rise in salinity, but overall in the lake salinity is 
Table 3 Statistical parameters of SI

\begin{tabular}{lllll}
\hline \multicolumn{2}{l}{ Salinity index $(\mathrm{SI})$} & & & \\
\hline Date & Min & Max & Average & SD \\
\hline 22 Jan & 0.07 & 0.14 & 0.09 & 0.02 \\
21 Feb & 0.09 & 0.16 & 0.12 & 0.03 \\
22 Mar & 0.12 & 0.2 & 0.15 & 0.03 \\
21 Apr & 0.08 & 0.24 & 0.16 & 0.04 \\
31 May & 0.15 & 0.49 & 0.29 & 0.1 \\
5 Jun & 0.32 & 0.46 & 0.38 & 0.02 \\
25 Jun & 0.19 & 0.34 & 0.25 & 0.05 \\
\hline
\end{tabular}

Table 4 Statistical parameters of NDHI

\begin{tabular}{lccll}
\hline \multicolumn{4}{l}{ Normalized difference haloarchaea index(NDHI) } \\
\hline Date & Min & Max & Average & SD \\
\hline 22 Jan & -0.23 & -0.07 & -0.03 & 0.04 \\
21 Feb & -0.32 & -0.003 & -0.1 & 0.03 \\
22 Mar & -0.44 & -0.11 & -0.19 & 0.02 \\
21 Apr & -0.81 & -0.12 & -0.3 & 0.08 \\
31 May & -0.75 & -0.09 & -0.43 & 0.03 \\
5 Jun & 0.06 & 0.45 & 0.4 & 0.02 \\
25 Jun & 0.2 & 0.74 & 0.61 & 0.08 \\
\hline
\end{tabular}

not that much high as it can be seen from Fig. 7. So during this time period of January to May, there is no presence of Haloarchaea microbes in the lake. Another reason is maybe the presence of algal bloom suppresses the reflection in the red band, so the NDHI becomes negative for all these months. But as June 2020 started, the salinity increases very much in the lake, and the lake becomes the breeding ground for Haloarchaea microbes and algae gets overpowered by these microbes. From Table 3 and Table 4 it can be inferred that during the month of June 2020, when salinity becomes very high throughout the lake then these microbes started to show their presence. By looking at Table 2 and Table 4, it can be seen that when the algal bloom is dominating the Haloarchaea microbes are almost negligible and vice-versa. The months of May and June are a very good example for this. During the later half of June, rainfall had happened in this region, and salinity also gets diluted in the lake, but these microbes do not get diminished. On the contrary, their presence gets increased in the lake.

Figure 8 shows the variation of the rainfall in the Buldhana district for June 2020, and it can be seen from the figure that after June 15, there has been a considerable amount of rainfall that had happened at this place. The rainfall data have been downloaded from the INDIA WRIS website, and it is a government website. Even this rainfall cannot diminish the effect of these microbes on the Lonar Lake (Fig. 9).

\section{Conclusions}

This study has been carried out to detect the change in the colour of Lonar lake with the help of S2A satellite imageries. The salinity of lake increases during the month of June 2020 then it attracts the Haloarchaea microbes as these microbes like to live in the high saline water. The emergence of these microbes in the lake had happened precisely between the dates 31 May and 5 June because from the Fig. 8, it can be seen that on 31 May there are almost negligible Haloarchaea microbes, but on June 5 whole lake had been covered by these microbes. These microbes produce pink colour pigments. When the rainfall occurs, the salinity of water bodies becomes diluted, so as the salinity recedes, these microbes should also get reduced, but in Lonar lake, the concentration of microbes 

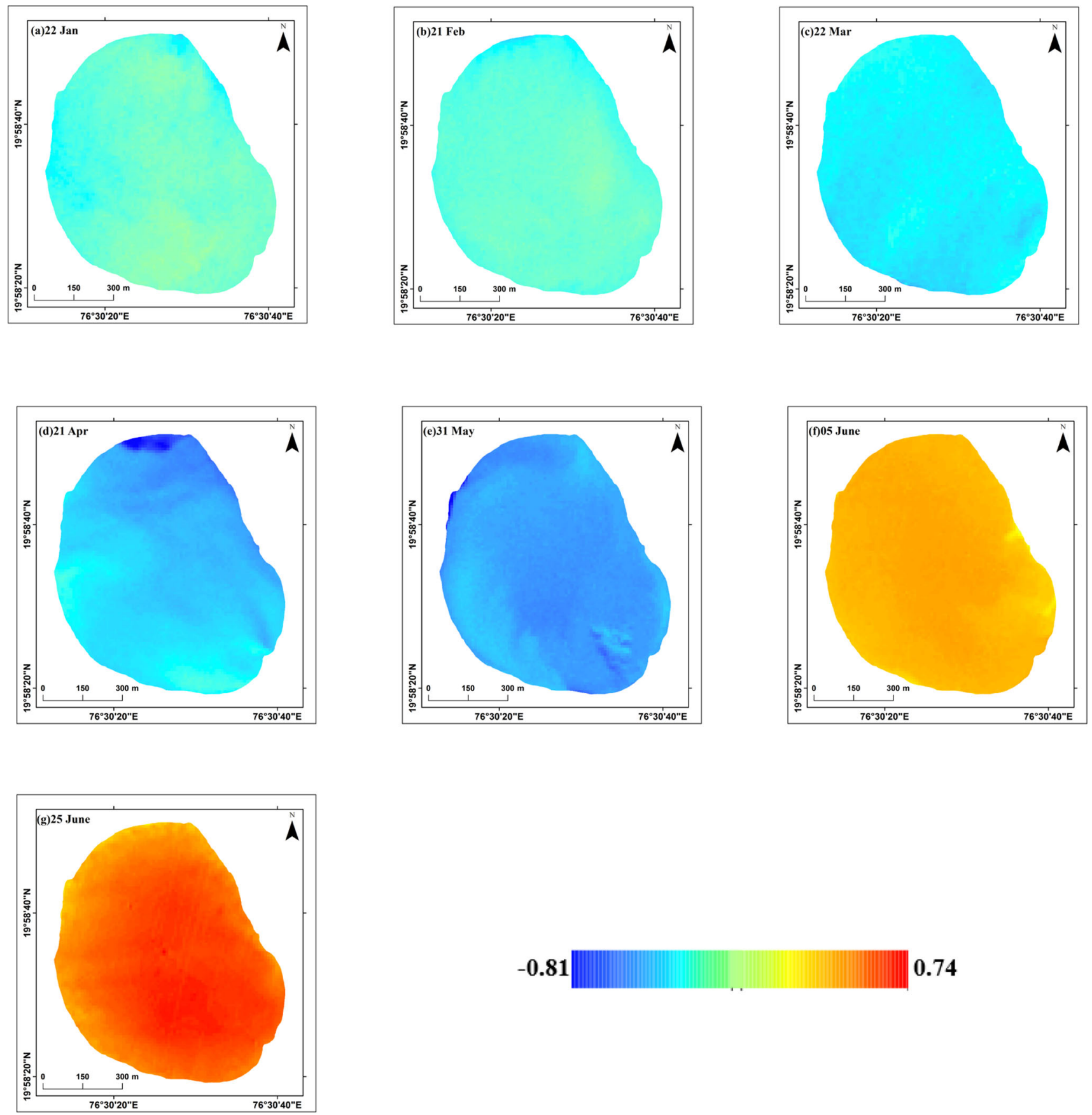

Fig. 8 Variation of NDHI in Lonar lake 


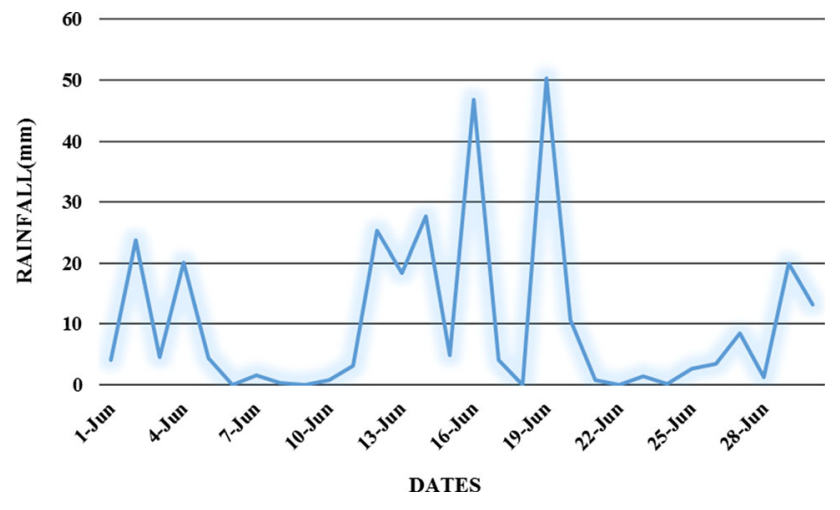

Fig. 9 Rainfall at Buldhana for June 2020

get increased on June 25. It will take a much longer time maybe before these microbes completely die down.

Acknowledgements Authors would like to take this opportunity to expresses their gratefulness towards Dr. Prabhat Kumar Singh Dixit, HOD of Civil Engineering Department, IIT (BHU), for constantly motivating to carry forward this study. Additionally, a special vote of thanks for Dr. Prithvish Nag (former Surveyor General of India) for reviewing and adding positive comments on this manuscript.

Funding Not applicable.

Availability of Data and Materials Data had been accessed through the GEE platform. https://earthengine.google.com. (accessed on 25,26,27 July 2020). The rainfall dataset had been downloaded from the INDIA WRIS portal. https://indiawris.gov.in/wris/ (accessed on 27 July 2020).

Code Availability Not applicable.

\section{Compliance with Ethical Standards}

Conflicts of interest Authors declare no conflict of interest.

\section{References}

Alawadi, F. (2010). Detection of surface algal blooms using the newly developed algorithm surface algal bloom index (SABI). Remote Sensing of the Ocean, Sea Ice, and Large Water Regions. https:// doi.org/10.1117/12.862096

Bresciani, M., Cazzaniga, I., Austoni, M., Sforzi, T., Buzzi, F., Morabito, G., \& Giardino, C. (2018). Mapping phytoplankton blooms in deep subalpine lakes from Sentinel-2A and Landsat-8. Hydrobiologia, 824(1), 197-214.

Budd, J. W., Beeton, A. M., Stumpf, R. P., Culver, D. A., \& Charles Kerfoot, W. (2001). Satellite observations of Microcystis blooms in western Lake Erie. Internationale Vereinigung für theoretische und angewandte Limnologie: Verhandlungen, 27(7), 3787-3793.

DasSarma, S., \& DasSarma, P. (2017). Halophiles. In: Encyclopedia of life sciences. Chichester :Wiley.

DasSarma, S., DasSarma, P., Laye, V. J., \& Schwieterman, E. W. (2020). Extremophilic models for astrobiology: Haloarchaeal survival strategies and pigments for remote sensing. Extremophiles, 24(1), 31-41.
Dong, J., Xiao, X., Menarguez, M. A., Zhang, G., Qin, Y., Thau, D., et al. (2016). Mapping paddy rice planting area in northeastern Asia with landsat 8 images, phenology-based algorithm and Google Earth Engine. Remote Sensing of Environment. https:// doi.org/10.1016/j.rse.2016.02.016

Gorji, T., Yildirim, A., Hamzehpour, N., Tanik, A., \& Sertel, E. (2020). Soil salinity analysis of Urmia lake basin using Landsat8 OLI and Sentinel-2A based spectral indices and electrical conductivity measurements. Ecological Indicators, 112, 106173.

Jia, B., Tang, Y., Tian, L., Franz, L., Alewell, C., \& Huang, J. H. (2015). Impact of fish farming on phosphorus in reservoir sediments. Scientific Reports, 5, 16617.

Joshi, A. A., Kanekar, P. P., Kelkar, A. S., Shouche, Y. S., Vani, A. A., Borgave, S. B., \& Sarnaik, S. S. (2008). Cultivable bacterial diversity of alkaline Lonar Lake India. Microbial Ecology, 55(2), 163-172.

Kennedy, S. P., Ng, W. V., Salzberg, S. L., Hood, L., \& DasSarma, S. (2001). Understanding the adaptation of Halobacterium species NRC-1 to its extreme environment through computational analysis of its genome sequence. Genome research, 11(10), $1641-1650$.

Khan, S., \& Abbas, A. (2007). Using remote sensing techniques for appraisal of irrigated soil salinity. Int. Congr. Model. Simul (MODSIM), Model. Simul. Soc. Aust. New Zealand, Bright, (January), https://www.mssanz.org.au/MODSIM07/MOD SIM07.htm.

Li, L., Yang, J., \& Wu, J. (2019). A method of watershed delineation for flat terrain using sentinel-2a imagery and DEM: A case study of the Taihu basin. ISPRS International Journal of GeoInformation, 8(12), 528.

Lonar lake in Maharashtra's Buldhana district turned pink due to 'Haloarchaea' microbes: probe. Resource Document. The Hindu. Retrieved July 28, 2020, from, https://www.thehindu.com/news/ national/lonar-lake-turned-pink-due-to-haloarchaea-microbesprobe/article32161619.ece.

Lonar lake tries on a rosy color. Resource document. NASA Earth Observatory. Retrieved July 30, 2020, from https://earthobserva tory.nasa.gov/images/146859/lonar-lake-tries-on-a-rosy-color.

Mahto, S. S., \& Kushwaha, A. P. (2018). An assessment of interseasonal surface water level fluctuation of Lonar Crater lake, Maharashtra, India Using multi-temporal Satellite dataset. American Journal of Remote Sensing, 6(1), 6-14.

Parab, B. (2020). Lonar lake mysteriously turns pink. Resource document. Deccan Chronicle. Retrieved July 28, 2020, from, https://www.deccanchronicle.com/nation/in-other-news/120620/ lonar-lake-mysteriously-turns-pink.html.

Pinjarkar,V. (2020). Lonar lake turns pink, scientists probe the cause. Resource document. The Times of India. Retrieved July 28, 2020, from https://timesofindia.indiatimes.com/city/nagpur/ lonar-lake-turns-pink-scientists-probe-the-cause/articleshow/ 76310704.cms.

Roy, D. P., Wulder, M. A., Loveland, T. R., Woodcock, C. E., Allen, R. G., Anderson, M. C., et al. (2014). Landsat-8: Science and product vision for terrestrial global change research. Remote sensing of Environment, 145, 154-172.

Roy, P. S., Behera, M. D., \& Srivastav, S. K. (2017). Satellite remote sensing: sensors, applications and techniques. Switzerland: Springer.

Sterner, R. W., Keeler, B., Polasky, S., Poudel, R., Rhude, K., \& Rogers, M. (2020). Ecosystem services of Earth's largest freshwater lakes. Ecosystem Services, 41, 101046.

Tambekar, D. H., \& Dhundale, V. R. (2012). Studies on the physiological and cultural diversity of bacilli characterized from Lonar lake (MS) India. Biosci Discov, 3(1), 34-39. 
Tambekar, D. H., Pawar, A. L., \& Dudhane, M. N. (2010). Lonar lake water: past and present. Nature, Environment and Pollution Technology, 9(2), 217-221.

Van der Werff, H., \& Van der Meer, F. (2016). Sentinel-2A MSI and Landsat 8 OLI provide data continuity for geological remote sensing. Remote Sensing, 8(11), 883.

Yannawar, V. B., \& Bhosle, A. B. (2013). Cultural eutrophication of Lonar lake, Maharashtra, India. International Journal of Innovation and Applied Studies, 3(2), 504-510.
Zurqani, H. A., Post, C. J., Mikhailova, E. A., Schlautman, M. A., \& Sharp, J. L. (2018). Geospatial analysis of land use change in the Savannah River basin using Google Earth Engine. International Journal of Applied Earth Observation and Geoinformation. https://doi.org/10.1016/j.jag.2017.12.006

Publisher's Note Springer Nature remains neutral with regard to jurisdictional claims in published maps and institutional affiliations. 